\title{
Pintar lo invisible, Pablo Amaringo Shuña
}

(1943-2009)

María Eugenia Yllia

La partida de Pablo Amaringo deja un enorme vacío en el mundo del arte amazónico contemporáneo. Su obra, realizada en un contexto alejado de la escena cultural limeña, pero especialmente de los parámetros del arte convencional, dio forma a un tipo de conocimiento invisible y milenario que constituye la base de la filosofia, medicina, religiosidad y estética de las sociedades amazónicas: el sagrado mundo de la ayahuasca'.

Procedente de una familia mestiza de origen andino y amazónico, Amaringo nació en 1943 en Puerto La Libertad, Tamanco, Requena (Loreto) y a los trece años, junto a su familia, se trasladó a Pucallpa, en donde desplegó su obra plástica y vivió el resto de su vida. Durante su niñez y adolescencia conoció en carne propia las propiedades curativas de la ayahuasca, pero fue recién a los veintiséis años que se introdujo en el mundo del chamanismo y vegetalismo ${ }^{2}$, y exploró intensamente sus asombrosos poderes visionarios y curativos. En este tiempo recorrió la Amazonía y se convirtió en un reconocido chamán, actividad que ejerció durante seis largos años hasta que la abandonó debido a que fue víctima del peligroso combate chamánico.

Fue el poder de la ayahuasca quien le vaticinó su destino como artista y creador de una escuela pictórica que tendría seguidores. Así fue. Convencido de que los espíritus se expresan a través de las imágenes, comenzó a pintar sus visiones y los asombrosos, incomprensibles y muchas veces aterradores efectos que produce en la percepción humana. Sus pinturas, difundidas a través del libro Ayahuasca Visions The religious iconography of a peruvian shaman $(1991)^{3}$ realizado en coautoría con Luis Eduardo Luna, desarrollaron un imaginario iconográfico compuesto por paisajes y arquitecturas fantásticas que describian insólitamente diversas regiones y culturas del mundo, seres zoomorfos, personajes híbridos; dioses y elementos mitológicos diversos y principalmente el despliegue de un cromatismo sicodélico, de colores rutilantes.

Amaringo vivió el arte como una praxis imprescindible para el desarrollo social y espiritual del individuo, debido a ello en 1988 creó Usko-Ayar, pensada con la firme consigna de elevar la vida de los jóvenes del entorno. Sin saberlo, su obra fue un referente en la trayectoria de artistas de otros contextos como Víctor Churay Roque, el pintor bora, cuyo estilo le abrió las puertas del color y a la introspección creativa.

Su pintura forma parte de diversas colecciones a nivel mundial y ha recibido premios y reconocimientos importantes en países como Suiza, Estados Unidos, Finlandia, entre otros de la escena artística global; sin embargo en nuestro medio como suele suceder con los grandes, fue por mucho tiempo casi ignorada. En los últimos años llegó al público limeño a partir de su participación en exposiciones colectivas como: La Soga de los muertos: el conocer desconocido del ayahuasca, realizada en el Museo de Arte de San Marcos (2006), Poder Verde, en el Centro Cultural de España (2009), ambas curadas por el artista plástico Christian Bendayán y Amazonía: Siete Visiones Contemporáneas en la Sala de Petroperú (2009).

ILLAPA rinde un sentido homenaje a este creador pionero que tendió puentes entre el arte amazónico peruano y la cultura global.

1 Traducido del quechua significa soga del ahorcado o enredadera del alma, brebaje milenario obtenido a base de la cocción del Banisteriopsis Caapi con la hoja Psychotria viridis.

2 Conocimiento ancestral de la intima relación entre el organismo humano y el mundo vegetal.

3 Los datos biográficos de Pablo Amaringo básicamente han sido tomados de esta publicación. 


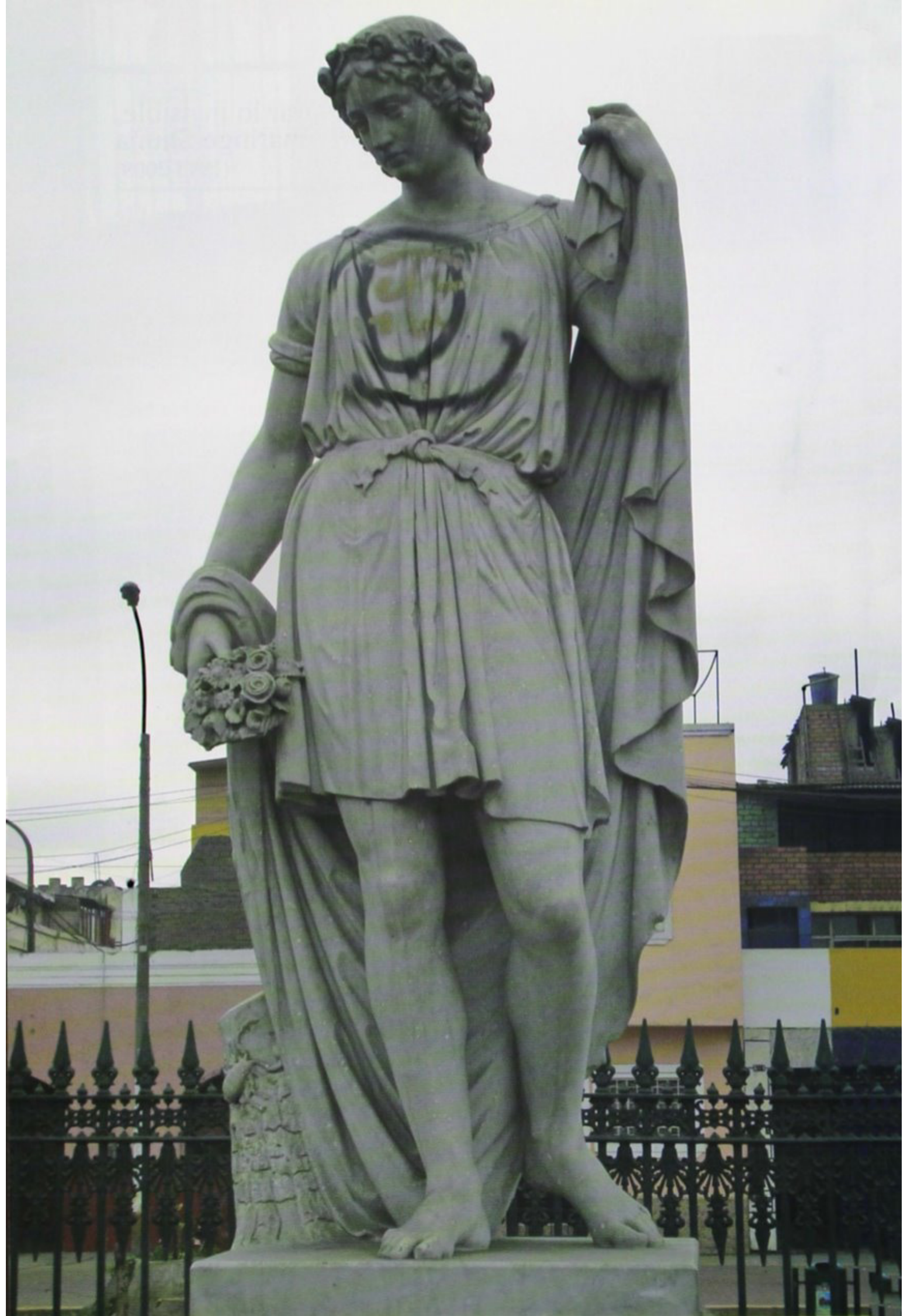

